\title{
Janet Carr
}

Janet Carr was one of the longest serving members of the editorial board of Cognitive Behavioural Psychotherapy. Her father was a missionary and headmaster of a Chinese school in Peking from 1919. Janet was born there in 1927 but the whole family returned to England in 1931 when her father became ill. She attended Moira House School in Eastbourne which was evacuated to Windermere during the war. She studied psychology at Reading from 1945 to 1948, and it was there she became firm friends with Ann and Alan Clarke. On graduating, she tried hard to get a job but, as she said later, nobody wanted me - 'not even the prison service'. Alan Clarke advised her to apply for the relatively recently established course in clinical psychology at the Maudsley hospital, where she duly started on the second course in 1949. To this day, trainees on that course complain that they never actually received their certificates, probably because Cyril Burt tried to prevent the University from recognising any Diploma course of which he was not head.

At the 50th Anniversary of the course in 1997, Janet and Bob Payne regaled the audience with vivid accounts of what it was like to be in at the beginning of clinical psychology in the UK. Monte Shapiro had been appointed director of the course and they learned respect for the scientific method. This was important to Janet in obtaining work as a clinical psychologist. In typical fashion, Janet mentioned the fun they had and the wonderful parties. Not only did she keep in touch with her fellow trainees, through one of them she met her husband, Eric Carr, a psychiatrist whom she married in 1954.

Between graduating and marriage, Janet worked in various child and adult mental health clinics in London and the south-east. After marriage, she and Eric had three children - Jim, Nick and Sally - Sally followed in her mother's footsteps. After eight years of being a full-time mother, Janet started working part-time. She was appointed as a research worker on a new project run by the MRC genetics research unit at the Maudsley to study all 54 babies born in 1964 with Down's syndrome in three London boroughs to ascertain their needs for educational provision. She was able to see children and controls to fit in with family commitments. Later, she enrolled for a PhD with Jack Tizard, by then at the Institute of Education.

While Janet's main task in the project was to assess the children's cognitive development, she was also concerned to find out about the impact of the children on their families. At that time, Down's syndrome was the largest group of children with severe intellectual handicap for whom a genetic cause had been found. Physically, the children were readily recognisable and the assumptions made were that their birth would put great strains on the family, including break-up. What Janet found through systematic and sensitive interviews shocked her. Mothers reported how professionals were indifferent to cruel in how they broke news of the diagnosis to parents and were pessimistic in the extreme about the children's futures. This resulted in her first paper in 1970 on telling parents about mongolism, as Down's syndrome was then called.

The following year, she was appointed to a lectureship at the Institute of Psychiatry working clinically at the newly established Hilda Lewis House. Its aim was to provide detailed multidisciplinary assessments of children's complex needs and devise interventions that would greatly involve the parents. This coincided with the advent of behaviour modification interventions. A great deal of work was going on at the Maudsley, developing behavioural interventions that could help previously intractable problems. Few were as intractable as the 
life-threatening self-injury, extreme violence, other 'challenging' behaviour that often resulted in removal from even a special school and, above all, exclusion from family. Together with John Corbett, child psychiatrist, over the next five years, Janet led a stellar team of psychologists at Hilda Lewis House including Glyn Murphy, Maria Callias and Patricia Howlin. There followed a stream of influential papers all building the case for recognising that families could learn to help their handicapped children and the children responded by great advances in development. In 1980, she published 'Helping your handicapped child: a step-by-step guide to everyday problems'. This was beautifully illustrated by Posy Simmonds and went to three reprints before Penguin persuaded her to write a second edition. Meanwhile, the dedicated team had started to work with groups of parents to teach them these techniques and approaches. This resulted in the text co-edited with me, 'Behaviour Modification for the Mentally Handicapped'. It also went to second edition in 1995.

Throughout all these achievements, Janet never lost sight of the original group of Down's children. She had followed them regularly until they were four years old. Although she published her findings in a book in 1975, she still kept in touch with the families, sending yearly Christmas cards. She had had no intention of undertaking further rounds of interviews, but as the children became 11 years old, she decided to do so.

Janet moved to St George's Hospital as regional tutor in the psychology of learning disability (nomenclature changed with every advance) where her work was supported fully by Professor Joan Bicknell and Professor Sheila Hollins. The emphasis on helping families continued and influenced many trainees.

She was persuaded by colleagues to follow up the children now aged 21 years. The habit continued and she saw them all again aged 30 years after she had retired from the NHS. She interviewed them again when they were 40 and again when 45 . Janet herself was 82 at this point. She persuaded her son Nick to come from Australia in 2014 to undertake the final round of visits when the children were aged 50 .

Throughout her life, Janet had many interests outside of work. Her mother had introduced her to skiing. She skied regularly and had a family ski reunion when she was 85. An avid Guardian reader, she regularly completed the crosswords. She loved music but regretted that hearing loss in later life interfered with enjoyment of opera. She played tennis until she was 86 . How anyone with this zest for life and all these active interests managed to find time to raise a family and also to work clinically and undertake ground-breaking clinical research is awe inspiring.

She won recognition from a number of parent-led organizations and was appointed OBE in 2015 for her work with children with Down's syndrome. To celebrate the end of the 50-year follow-up, Dame Sheila Hollins hosted an afternoon tea party in the House of Lords. Many of the now grown-up children came to show their appreciation.

Janet had started to write up an account of these unique studies when she was hit by a car crossing a road near her home. She survived but suffered a serious break in her pelvis, and a broken hip and left arm. She made a remarkable recovery but from then on needed a stick for walking. In fact, her health declined from then on. She went to live with her daughter in Wales and moved with her family to Shrewsbury where she died peacefully on 17 March 2020. It is an enormous privilege to have known Janet and to have worked with her. Her pioneering work in applying behaviour modification paved the way for many other studies that have graced the pages of this journal.

William Yule

London, 6 August 2020 